\title{
PENDUGAAN BIOMASSA IKAN PELAGIS DI PERAIRAN TELUK TOMINI DENGAN METODE AKUSTIK BIM TERBAGI
}

\author{
Mohammad Natsir"), Bambang Sadhotomo*), dan Wudianto")
}

\begin{abstract}
ABSTRAK
Penelitian ini bertujuan untuk mendapatkan estimasi biomassa ikan pelagis di wilayah perairan Teluk Tomini dengan menggunakan metode akustik, khususnya metode akustik bim terbagi, yang penggunaannya untuk keperluan eksplorasi sumber daya perikanan, khususnya ikan pelagis telah berkembang dengan pesat di beberapa negara maju. Penelitian ini dilaksanakan di perairan Teluk Tomini dari tanggal 22 Juli sampai dengan 5 Agustus 2003. Pendugaan biomassa ikan pelagis dilakukan pada perairan dari permukaan sampai dengan kedalaman $150 \mathrm{~m}$. Dari hasil penelitian diperoleh rata-rata nilai densitas ikan absolut untuk masingmasing strata kedalaman adalah 5,8 ekor $1.000 \mathrm{~m}^{-3}$ untuk strata kedalaman 0 sampai dengan $25 \mathrm{~m}, 7,2$ ekor $1.000 \mathrm{~m}^{-3}$ untuk strata kedalaman 25 sampai dengan $50 \mathrm{~m}, 2,2$ ekor $1.000 \mathrm{~m}^{-3}$ untuk strata kedalaman 50 sampai dengan $100 \mathrm{~m}, 0.8$ ekor $1.000 \mathrm{~m}^{-3}$ untuk strata kedalaman 100 sampai dengan $150 \mathrm{~m}$. Besaran nilai estimasi stok biomassa ikan secara keseluruhan untuk perairan Teluk Tomini yang memiliki luas sekitar $17.220 \mathrm{mil}^{2}$ (sekitar $59.000 \mathrm{~km}^{2}$ ) dari lapisan permukaan sampai dengan kedalaman $150 \mathrm{~m}$ adalah 303.624 ton. Dari biomassa total tersebut terdiri atas ikan pelagis kecil 204.695 ton atau $67 \%$ dan ikan pelagis besar 98.930 ton atau $33 \%$. Biomassa ikan pelagis kecil cenderung menurun dengan bertambahnya kedalaman, sedangkan biomassa ikan pelagis besar memiliki kecenderungan meningkat seiring dengan meningkatnya kedalaman perairan.
\end{abstract}

\section{ABSTRACT: Estimation of the pelagic fish abundance in the waters of Tomini Bay using split beam acoustic method. By: Mohammad Natsir, Bambang Sadhotomo, and Wudianto}

The current study aims to estimate pelagic fish abundance in Tomini Bay waters using acoustic methods, particularly split beam acoustic for which the use, in fisheries resources exploration was rapidly developed in several developed countries and research institutes. This study was conducted in Tomini Bay waters from $22^{n d}$ July 2003 until $5^{\text {th }}$ August 2003. The analysis resulted the average of densities for each stratum were 5.8 ind. $1,000 \mathrm{~m}^{-3}$ for $0-25 \mathrm{~m}$ stratum, 7.2 ind. $1,000 \mathrm{~m}^{-3}$ for $25-50 \mathrm{~m}$ stratum, 2.2 ind. $1,000 \mathrm{~m}^{-3}$ for $50-100 \mathrm{~m}$ stratum, and 0.8 ind. $1.000 \mathrm{~m}^{-3}$ for $100-150 \mathrm{~m}$ stratum. The total biomass of pelagic fish in Tomini Bay (area around of $59,000 \mathrm{~km}^{2}$ ) was estimated around 303,624 ton. Total biomass for small pelagic fish was about 204,695 ton $(67 \%)$, whereas the total biomass for large pelagic fish was 98,930 ton (33\%). Small pelagic biomass was decreasing unanimously to the increasing of the depth, in contrast, the biomass of large pelagic fish was increasing when the depth of waters was increase.

KEYWORDS: $\quad$ estimation, abundance, pelagis fish, acoustic, Tomini Bay

\section{PENDAHULUAN}

Teluk Tomini merupakan salah satu perairan di Indonesia yang sangat potensial untuk pengembangan usaha perikanan. Potensi sumber daya perikanan pelagis, baik itu pelagis kecil maupun pelagis besar telah dimanfaatkan oleh nelayannelayan yang tinggal di sekitar perairan Teluk Tomini, di antaranya nelayan berasal dari Manado, Marisa, Bitung, Gorontalo, Parigi, Poso, Pagimana, dan Luwuk. Kajian tentang potensi sumber daya perikanan di wilayah ini mutlak dibutuhkan untuk memberikan gambaran mengenai status stoknya.

Informasi tentang dugaan biomassa ikan di suatu perairan merupakan hal yang sangat penting dalam pengelolaan sumber daya perikanan di wilayah tersebut. Beberapa metode dapat digunakan untuk menduga nilai biomassa ikan di suatu wilayah perairan. Salah satu metode yang dapat diaplikasikan adalah dengan menggunakan metode akustik.
Menurut MacLennan \& Simmonds (1992) pendugaan stok ikan yang diperoleh melalui pendekatan akustik memiliki sedikit perbedaan dengan konsep pedugaan stok dengan pendekatan biologi seperti yang dikembangkan Gulland (1983).

Penggunaan echo sounder dan echo integrator untuk keperluan eksplorasi sumber daya perikanan khususnya ikan-ikan pelagis, pada tahun terakhir ini berkembang dengan pesat terutama di negara-negara maju dan pada beberapa lembaga penelitian. Peralatan echo integrator digunakan untuk mendapatkan integrasi sinyal echo dari echo sounder bim tunggal, bim ganda, maupun bim terbagi atau sonar konvensional. Tingkat ketepatan teknik ini sangat tinggi dan menguntungkan sehingga dapat digunakan sebagai penduga kelimpahan ikan di suatu perairan (Kailola \& Trap, 1984).

Tulisan ini memberikan gambaran tentang estimasi stok ikan pelagis di wilayah perairan Teluk Tomini

\footnotetext{
Peneliti pada Balai Riset Perikanan Laut, Jakarta
} 
melalui metode akustik, khususnya metode akustik bim terbagi (split beam acoustic system). Dari hasil ini diharapkan dapat memberikan informasi tentang besaran biomassa ikan pelagis sehingga dapat digunakan sebagai bahan kebijakan dalam pemanfaatan sumber daya ikan secara optimal dan berkelanjutan.

\section{BAHAN DAN METODE}

Penelitian ini dilaksanakan di perairan Teluk Tomini pada tanggal 22 Juli sampai dengan 5 Agustus 2003, dengan menggunakan KM. Malalugis, kapal latih dari Balai Pelatihan Perikanan Bitung. Data akustik diperoleh dengan alat echo sounder SIMRAD EY 500 yang ditempatkan di atas kapal dengan penempatan transducer bim terbagi (split beam echosounder) yang ditempatkan pada sisi kanan luar kapal dengan sistem side mounted. Dalam pengambilan data akustik digunakan bentuk tansek sistematik paralel (Mac Lennan, 1990) seperti disajikan pada Gambar 1.

\section{Perhitungan Biomassa Jumlah Individu}

Data yang terkumpul dari hasil akuisisi dianalisis menggunakan software EP 500 dengan elementary distance sampling unit sepanjang 1 mil, analisis terhadap hasil akuisisi ini menghasilkan nilai rata-rata densitas absolut dengan satuan ind. $\mathrm{m}^{-3}$ untuk masing-masing strata kedalaman, nilai densitas yang digunakan adalah nilai densitas rata-rata untuk seluruh transek pada sepanjang jalur pelayaran. Selanjutnya, dari nilai densitas rata-rata ini didapatkan jumlah individu per strata kedalaman dengan menggunakan persamaan:

$$
n i=\Sigma\left(\rho^{\star} \vee i\right)
$$

di mana:

$$
\begin{aligned}
& \mathrm{ni}=\text { Jumlah indvidu strata kedalaman ke-i } \\
& \rho=\text { Rata-rata volume densitas } \\
& \mathrm{Vi}=\text { Volume perairan strata kedalaman ke-i }
\end{aligned}
$$

\section{Komposisi Ukuran}

Secara akustik, hubungan antara TS (target strength) dengan backscattering crosssection $\left(\sigma_{\mathrm{bs}}\right)$ adalah sebagai berikut:

$\mathrm{TS}=10 \log \sigma_{\mathrm{bs}}$

Sehingga ukuran panjang ikan ( $L$ ) berhubungan juga dengan backscattering crossection $\left(\sigma_{\mathrm{bs}}\right)$ dengan persamaan $\sigma_{\mathrm{bs}}=\mathrm{aL}^{2}$, dengan demikian hubungan antara target strength (TS) dan L (panjang ikan) menjadi sebagai berikut:

$$
T S=20 \log L+A
$$

di mana:

$A=$ Nilai target strength untuk $1 \mathrm{~cm}$ panjang ikan (normalized target strength) nilai ini tergantung pada spesies ikan

Khusus untuk ikan-ikan yang mempunyai gelembung renang (bladder fish), hubungan linear tersebut sudah banyak diteliti dan diuji kebenarannya

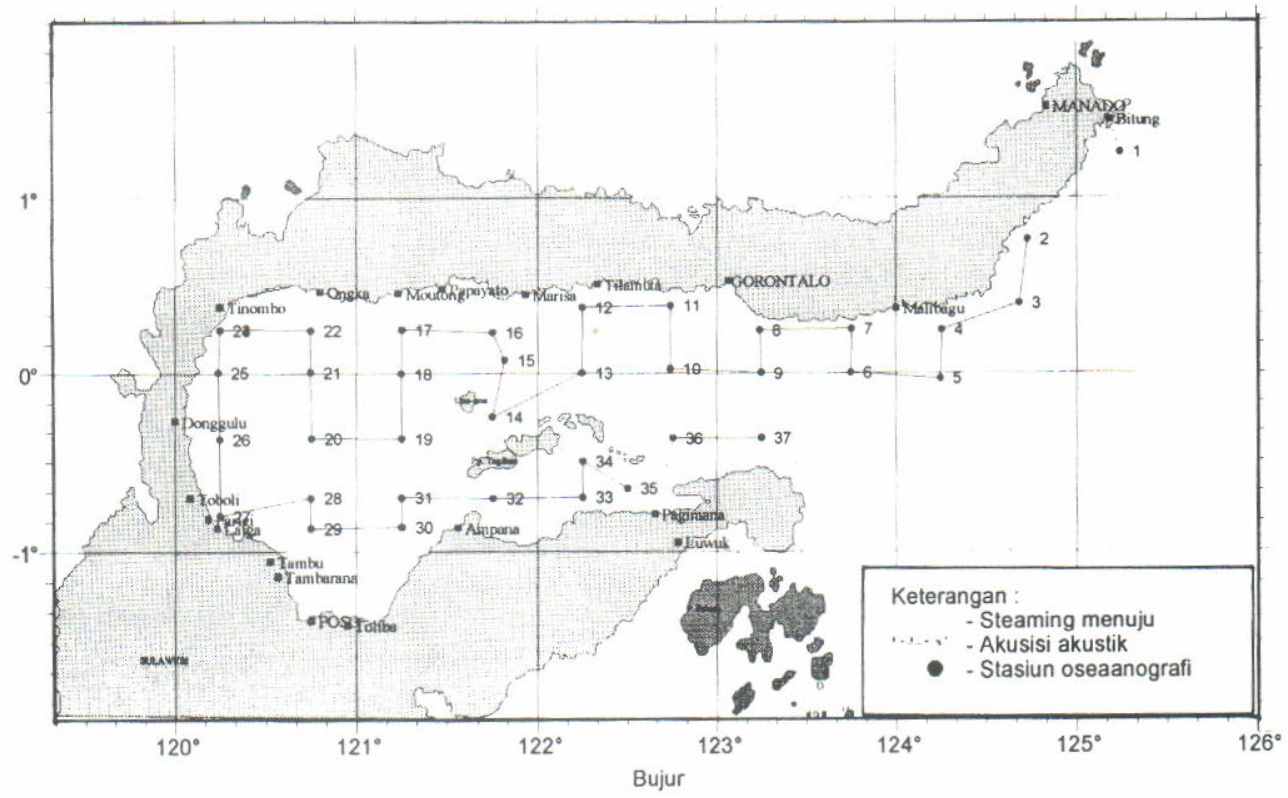

Gambar 1. Peta menunjukkan transek survei akustik di perairan Teluk Tomini Figure1. Map showing the acoustic survey transect in Tomini Bay. 
(Foote, 1987 dalam Arnaya, 1991b), akan tetapi untuk ikan-ikan yang tidak mempunyai gelembung renang (bladderless fish) memerlukan penelitian lebih lanjut.

Besaran nilai $20 \mathrm{log} L$ dalam persamaan (3) di atas juga bervariasi karena sangat tergantung dari spesies ikan dan faktor-faktor instrumen yang digunakan. Untuk bladder fish physoclist (ikan dengan gelembung renang tertutup) nilai $A$ adalah $-67,5 \mathrm{~dB}$ dan untuk bladder fish physostomes (ikan dengan gelembung renang terbuka) nilai $A$ adalah $-71,9 \mathrm{~dB}$. Sedangkan bagi ikan yang tidak memiliki gelembung renang (bladderless fish) besarnya nilai A adalah $-80 \mathrm{~dB}$ (Foote, 1987 dalam Arnaya, 1991b).

Untuk penelitian saat ini besaran nilai $A$ (normalized target strength) yang digunakan adalah $-80 \mathrm{~dB}$, yaitu untuk jenis ikan yang tidak memiliki gelembung renang (bladderless fish), karena berdasarkan pada data hasil tangkapan sebagian besar ikan pelagis yang tertangkap adalah jenis ikan malalugis (Decapterus macarellus). Ikan malalugis tergolong dalam jenis ikan yang tidak memiliki gelembung renang.

Menurut Maclennan \& Simmonds (1992) konversi panjang ikan dugaan menjadi bobot dugaan dilakukan dengan persamaan yang menjelaskan hubungan panjang bobot dari spesies ikan yang akan diestimasi yaitu:

$$
\mathrm{W}=\mathrm{aL}^{\mathrm{b}}
$$

di mana:

$$
\begin{array}{ll}
\mathrm{W} & =\text { Bobot ikan } \\
\mathrm{L} & =\text { Panjang ikan } \\
\mathrm{a} \text { dan } \mathrm{b} & =\text { Konstanta untuk spesies tertentu }
\end{array}
$$

Selanjutnya, karena bentuk persamaan target strength adalah persamaan logaritmik dan persamaan panjang bobot bukan merupakan persamaan yang linier, maka persamaan panjang bobot yang digunakan untuk mengkonversi panjang dugaan menjadi bobot dugaan menjadi seperti berikut:

$$
W t=a\left\{\sum_{i}^{i}\left\{n i(L i+\Delta L / 2)^{b+1}-(L i-\Delta L / 2)^{b+1}\right\} /\{(b+1) \Delta L\}\right\}
$$

di inana:

$$
\begin{aligned}
& \text { Wt }=\text { Bobot total } \\
& \mathrm{a}, \mathrm{b}=\text { Konstanta untuk spesies tertentu } \\
& \mathrm{ni}=\text { Jumlah individu pada kelas ke- } \mathrm{i} \\
& \mathrm{Li}=\text { Nilai tengah dari kelas panjang ke-i } \\
& \Delta \mathrm{L}=\text { Selang kelas panjang }
\end{aligned}
$$

\section{HASIL DAN BAHASAN}

\section{Densitas Absolut Rata-Rata}

Untuk mendapatkan rata-rata densitas ikan pelagis dibuat beberapa stratifikasi kedalaman antara lain 0 sampai dengan $25 \mathrm{~m}, 25$ sampai dengan $50 \mathrm{~m}, 50$ sampai dengan $100 \mathrm{~m}$, dan 100 sampai dengan 150 $\mathrm{m}$. Volume densitas absolut rata-rata yang diperoleh untuk tiap strata kedalaman dapat dilihat pada Tabel 1 dan Gambar 2. Densitas rata-rata tertinggi terdeteksi pada strata kedalaman 25 sampai dengan $50 \mathrm{~m}$ yaitu 7,195 ind $1.000 \mathrm{~m}^{-3}$. Selanjutnya, densitas menunjukkan pola menurun terhadap kedalaman, rendahnya densitas pada strata kedalaman 100 sampai dengan $150 \mathrm{~m}$ diperkirakan disebabkan adanya lapisan termoklin pada strata kedalaman ini.

Pada penelitian ini sebagai batasan perairan Teluk Tomini adalah daratan Sulawesi bagian dalam di

\begin{tabular}{|c|c|c|c|c|c|c|c|c|c|c|c|c|c|}
\hline \multirow{2}{*}{ Strata } & \multicolumn{12}{|c|}{ Nilai target strength (dB) } & \multirow{2}{*}{ Total } \\
\hline & -60 & -57 & -54 & -51 & -48 & -45 & -42 & -39 & -36 & -33 & -30 & -27 & \\
\hline $0-25 \mathrm{~m}$ & 1.540 & 695 & 125 & 13 & 7 & 5 & 3 & 1 & 0 & 0 & 0 & 0 & 2.389 \\
\hline $25-50 \mathrm{~m}$ & 6.858 & 7.768 & 1.628 & 228 & 38 & 14 & 10 & 1 & 1 & 0 & 0 & 0 & 16546 \\
\hline $50-100 \mathrm{~m}$ & 6.961 & 9.841 & 2.631 & 661 & 185 & 53 & 28 & 16 & 7 & 1 & 0 & 0 & 20.384 \\
\hline $100-150 \mathrm{~m}$ & 3.512 & 6.315 & 1.558 & 299 & 134 & 79 & 40 & 12 & 4 & 3 & 2 & 1 & 11.959 \\
\hline
\end{tabular}
bagian utara, daratan Sulawesi bagian dalam di bagian barat, daratan Sulawesi bagian dalam di bagian selatan dan Bujur $124^{\circ} \mathrm{BT}$ di bagian timur. Luas lahan ini diperkirakan sekitar $17.220 \mathrm{mil}^{2}$, atau

Tabel 1. Rata-rata densitas absolut ikan pelagis berdasarkan pada strata kedalaman di perairan Teluk Table 1. Average of the absolute density for pelagic fish by depth stratum in Tomini Bay

\begin{tabular}{cccc} 
Strata kedalaman & $\begin{array}{c}\text { Densitas } \\
\text { pelagis kecil }\end{array}$ & $\begin{array}{c}\text { Densitas } \\
\text { pelagis besar }\end{array}$ & $\begin{array}{c}\text { Densitas total } \\
\text { (ind. 1.000 } \text { m }^{-3} \text { ) }\end{array}$ \\
\hline $0-25 \mathrm{~m}$ & 5,791 & 0,010 & $5,800 \pm 13,5$ \\
$25-50 \mathrm{~m}$ & 7,190 & 0,005 & $7,195 \pm 14,2$ \\
$50-100 \mathrm{~m}$ & 2,192 & 0,006 & $2,198 \pm 5,8$ \\
$100-150 \mathrm{~m}$ & 0,784 & 0,004 & $0,788 \pm 7,7$ \\
\hline
\end{tabular}

Tabel 2. Jumlah individu ikan berdasarkan pada target strength dan strata kedalaman

Table 2. Number of individual fish based on target strength and depth stratum 
sekitar $59.000 \mathrm{~km}^{2}$. Dari luas lahan ini dapat dihitung volume perairan untuk strata kedalaman 1 (0 sampai dengan $25 \mathrm{~m}$ ) sampai dengan strata kedalaman 4 (100 sampai dengan $150 \mathrm{~m}$ ) sehingga besaran nilai biomassa ikan secara keseluruhan di perairan Teluk Tomini dapat dihitung.
Dari Tabel 2, 3, dan Gambar 2, 3 dapat terlihat bahwa target paling banyak terdeteksi pada strata kedalaman 2 (25 sampai dengan $50 \mathrm{~m}$ ), target dengan ukuran kecil, yaitu target dengan nilai target strength kurang dari $-54 \mathrm{~dB}$ cenderung meningkat menurut kedalaman sampai pada strata kedalaman

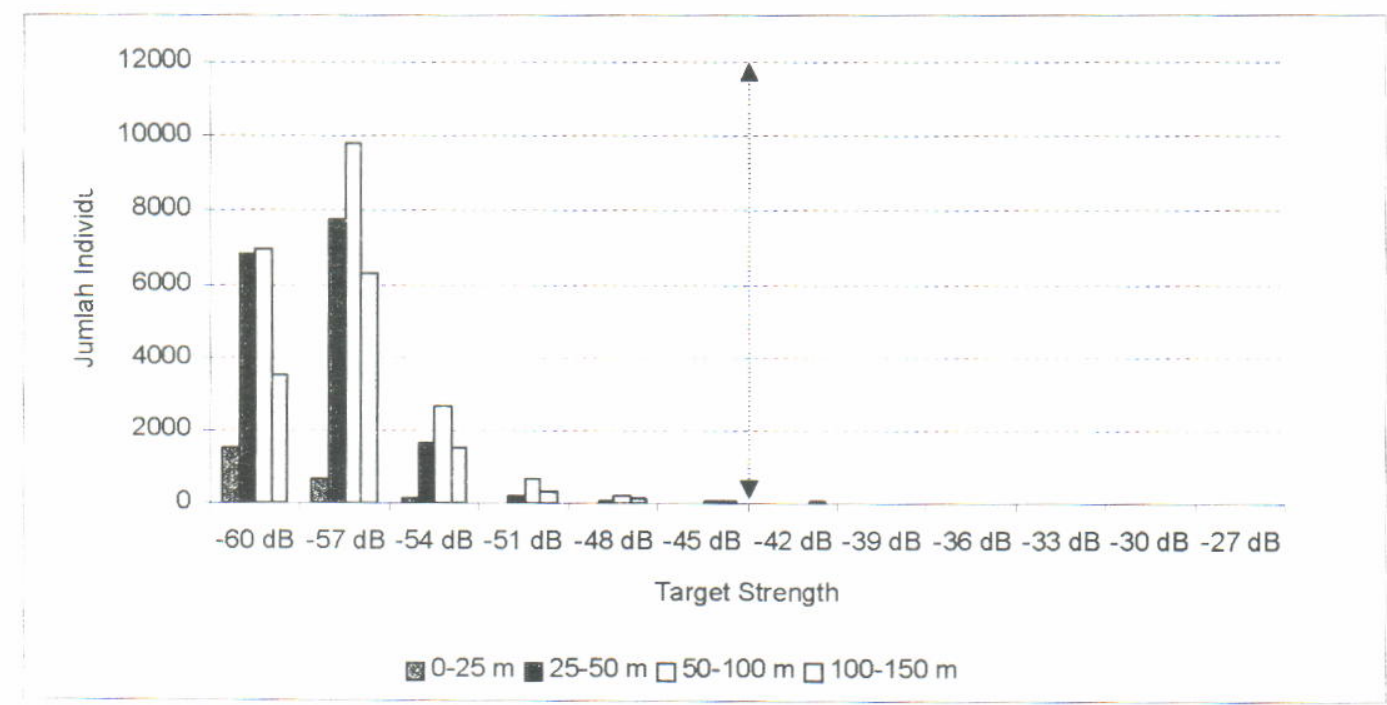

Gambar 2. Jumlah individu berdasarkan pada nilai target pada setiap strata kedalaman Figure 2. Number of fish based on target strength for each depth stratum.

Tabel 3. Komposisi (\%) berdasarkan pada nilai target strength ikan dan strata kedalaman Table 3. Composition (\%) based on the target strength value and depth stratum

\begin{tabular}{|c|c|c|c|c|c|c|c|c|c|c|c|c|}
\hline \multirow{2}{*}{ Strata } & \multicolumn{12}{|c|}{ Nilai target strength (dB) } \\
\hline & -60 & -57 & -54 & -51 & -48 & -45 & -42 & -39 & -36 & -33 & -30 & -27 \\
\hline $0-25 \mathrm{~m}$ & 64,5 & 29,1 & 5,2 & 0,5 & 0,3 & 0,2 & 0,1 & 0,0 & 0,0 & 0,0 & 0,0 & 0,0 \\
\hline $25-50 m$ & 41,4 & 46,9 & 9,8 & 1,4 & 0,2 & 0,1 & 0,1 & 0,0 & 0,0 & 0,0 & 0,0 & 0,0 \\
\hline $50-100 \mathrm{~m}$ & 34,1 & 48,3 & 12,9 & 3,2 & 0,9 & 0,3 & 0,1 & 0,1 & 0,0 & 0,0 & 0,0 & 0,0 \\
\hline $100-150 \mathrm{~m}$ & 29,4 & 52,8 & 13,0 & 2,5 & 1,1 & 0,7 & 0,3 & 0,1 & 0,0 & 0,0 & 0,0 & 0,0 \\
\hline
\end{tabular}

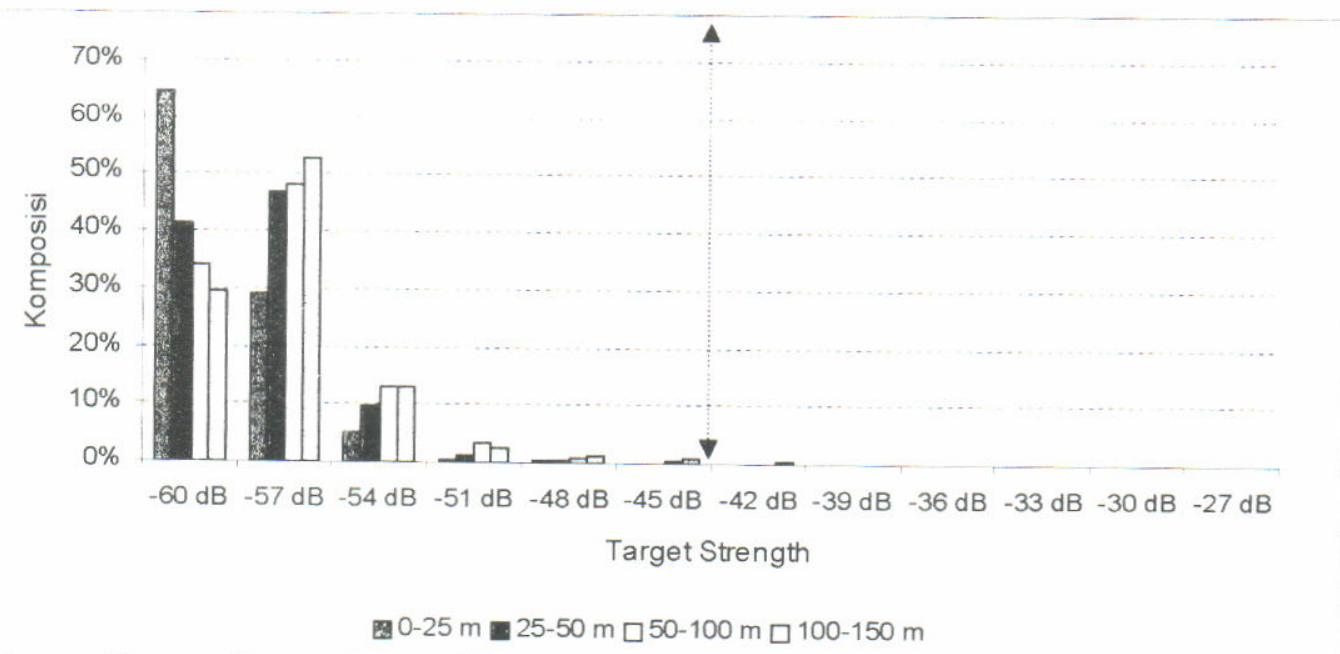

Gambar 3. Komposisi individu berdasarkan pada target strength pada setiap strata kedalaman Figure 3. Composition of individual based on target strength for each depth stratum. 
50 sampai dengan 100 m, kemudian menurun seiring bertambahnya kedalaman, sedangkan target dengan ukuran lebih besar, target dengan nilai target strength lebih dari $-45 \mathrm{~dB}$ cenderung meningkat berdasarkan pada semakin dalam perairan yakni strata 100 sampai dengan $150 \mathrm{~m}$.

Koinposisi tiap strata kedalaman lebih jelas menunjukkan pola peningkatan komposisi target dengan nilai target strength yang lebih besar seiring dengan meningkatnya kedalaman. Secara umum, ikan-ikan dengan ukuran yang lebih besar lebih banyak terdeteksi pada kedalaman yang lebih dalam, hal ini sesuai dengan perbedaan swimming layer dari masing-masing ukuran ikan dugaan di mana ikan-ikan dengan ukuran lebih besar cenderung berenang di kedalaman yang lebih dalam dibandingkan ikan-ikan yang berukuran kecil.

\section{Hubungan Panjang Bobot}

Hubungan panjang bobot yang digunakan dibagi menjadi 2 kategori yaitu ikan pelagis kecil dan ikan pelagis besar, pembagian kriteria tersebut didasarkan pada nilai target strength ikan, di mana ikan-ikan dengan nilai target strength kurang dari $-42 \mathrm{~dB}$ digolongkan ikan pelagis kecil, sedangkan ikan-ikan dengan nilai target strength lebih dari $-42 \mathrm{~dB}$ termasuk dalam kategori ikan pelagis kecil (Pasaribu et al. 1991 dalam Hutahean (1999).

Proses konversi panjang ikan dugaan dari nilai target strength dilakukan dengan menggunakan persamaan 3 dengan nilai konstanta $-80 \mathrm{~dB}$. Besaran nilai konstanta untuk ikan-ikan tanpa gelembung renang berdasarkan pada eksperimen yang telah dilakukan oleh Edwards \& Amstrong (1984), Armstrong (1986), Foote et al. (1990) dalam Maclennan \& Simmonds (1992). Dengan asumsi ikanikan tanpa gelembung renang di Teluk Tomini mengikuti persamaan dari hasil penelitian-penelitian sebelumnya yang telah dilakukan untuk ikan-ikan tanpa gelembung renang.

\section{Ikan Pelagis Kecil}

Persamaan panjang bobot yang dipakai dalam proses konversi panjang bobot ikan pelagis dari panjang ikan dugaan adalah ikan pelagis kecil dominan di perairan Teluk Tomini yaitu ikan malalugis (Decapterus macarellus). Dari Gambar 4 dapat terlihat hubungan antara panjang bobot ikan malalugis memiliki persamaan $W=0,01032 L^{3.06549 d}$ dengan satuan konversi adalah $\mathrm{cm}$ menjadi gram, persamaan inilah yang dipakai dalam proses penghitungan biomassa total ikan pelagis kecil di perairan Teluk Tomini.

\section{Ikan Pelagis Besar}

Proses konversi panjang ikan dugaan menjadi nilai bobot ikan dugaan untuk ikan pelagis besar dilakukan dengan menggunakan persamaan panjang bobot dari madidihang yellowfin tuna (Thunnus albacares) yang merupakan spesies ikan pelagis besar dominan yang ada di Teluk Tomini. Persamaan panjang bobot yang diperoleh untuk ikan pelagis besar (madidihang) adalan $W=0,000019 \quad L^{2.976}$ seperti terlihat pada Gambar 5

\section{Nilai Dugaan Stok}

Satuan (unit) yang digunakan untuk dugaan stok ikan secara keseluruhan yang diperoleh dari hasil perhitungan metode akustik adalah ton. Nilai biomassa ini merupakan nilai biomassa yang mewakili lahan $17.220 \mathrm{mil}^{2}$, atau lebih dari $59.000 \mathrm{~km}^{2}$. Dari hasil tersebut didapatkan biomassa total perairan Teluk Tomini adalah 303.624 ton $\mathrm{km}^{-2}$, biomassa ini terbagi pada masing-imasing strata kedalaman dan nilai panjang ikan dugaan.

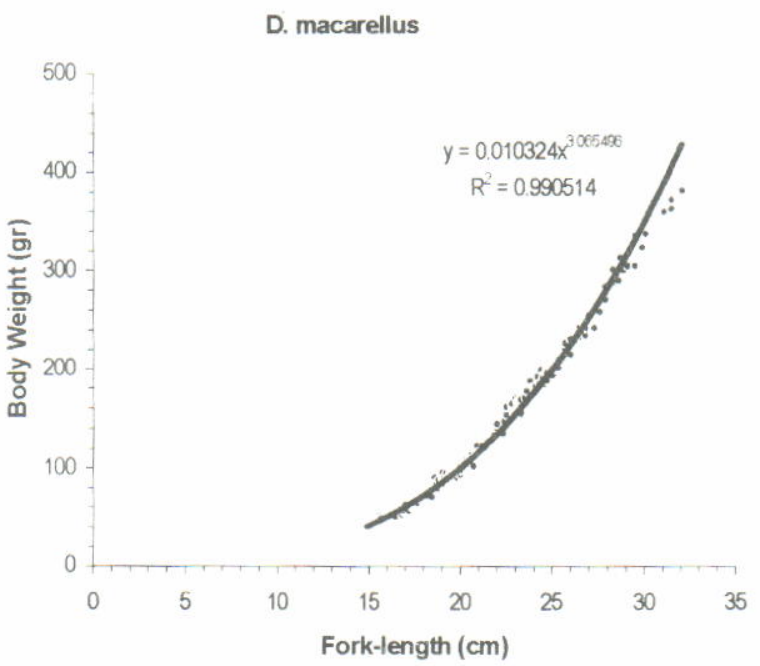

Gambar 4. Hubungan panjang bobot ikan malalugis (Decapterus macarellus).

Figure 4. Length weight relationship of Decapterus macarellus. 


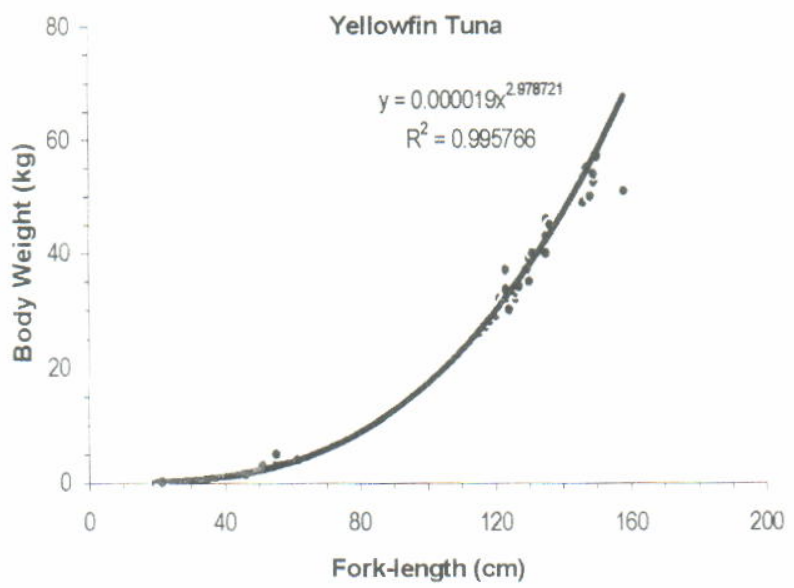

Gambar 5. Hubungan panjang bobot ikan madidihang (Thunnus albacares).

Figure 5. Length weight relationship of yellowfin tuna (Thunnus albacares).

Pada Tabel 4 dapat dilihat bahwa nilai biomassa yang diperoleh menunjukkan peningkatan seiring dengan bertambahnya kedalaman, dengan biomassa terbesar terdapat pada strata kedalaman 100 sampai dengan $150 \mathrm{~m}$ yaitu 119.587 ton, sedangkan nilai dugaan biomassa terkecil terdapat pada strata kedalaman 50 sampai dengan 100 m yaitu 12.017 ton, kecilnya biomassa di strata kedalaman ini diduga karena pada strata kedalaman ini adalah daerah termoklin yang memang kurang cocok untuk hidup bagi ikan pelagis karena adanya perubahan suhu yang relatif mencolok (Laevastu \& Hayes, 1981).

Tabel 4. Nilai biomassa ikan pelagis pada masing-masing strata kedalaman

Table 4. Biomass value of pelagic fish by depth stratum

\begin{tabular}{cccc}
\hline Strata kedalaman & & Biomassa (ton) & Total \\
\cline { 2 - 4 } & Pelagis kecil & Pelagis besar & 76.973 \\
$25-50 \mathrm{~m}$ & 67.348 & 9.625 & 95.047 \\
$50-100 \mathrm{~m}$ & 88.504 & 6.542 & 12.017 \\
$100-150 \mathrm{~m}$ & 8.309 & 3.708 & 119.587 \\
\hline Total & 40.534 & 79.053 & 303.624 \\
\hline
\end{tabular}

Dari hasil nilai biomassa yang diperoleh dapat dilakukan pembagian nilai biomassa ikan pelagis kecil dan biomassa ikan pelagis besar. Pada Tabel 5 dapat dilihat bahwa biomassa di perairan didominasi biomassa ikan pelagis kecil yaitu 204.695 ton atau lebih dari $67 \%$ dari total biomassa, sedangkan densitas ikan pelagis besar adalah 98.930 ton atau $33 \%$ dari total biomassa. Hal ini, sesuai dengan fenomena pada piramida makanan di mana mangsa (prey) yang dalam hal ini ikan pelagis kecil memiliki ketersediaan dalam perairan dalam jumlah yang lebih banyak dibandingkan pemangsa (predator).

Tabel 5. Nilai Kepadatan (ton $\mathrm{km}^{-2}$ ) ikan pelagis kecil dan ikan pelagis besar per strata kedalaman Table 5. Densiti (in ton per square $\mathrm{km}$ ) of small pelagic and large pelagic by depth stratum

\begin{tabular}{cccc}
\hline \multirow{2}{*}{ Strata kedalaman } & \multicolumn{3}{c}{ Kepadatan (ton $\mathbf{K m}^{-2}$ ) } \\
\cline { 2 - 4 } & Pelagis kecil & Pelagis besar & Total \\
\hline $0-25 \mathrm{~m}$ & 1,141 & 0,163 & 1.305 \\
$25-50 \mathrm{~m}$ & 1,500 & 0,111 & 1.611 \\
$50-100 \mathrm{~m}$ & 0,141 & 0,063 & 0.204 \\
$100-150 \mathrm{~m}$ & 0,687 & 1,340 & 2.027 \\
\hline Total & $\mathbf{3 , 4 6 9}$ & $\mathbf{1 , 6 7 7}$ & $\mathbf{5 . 1 4 6}$
\end{tabular}

Pada Gambar 6 dapat dilihat sebaran biomassa menurut kedalaman untuk ikan-ikan pelagis besar dan ikan pelagis kecil. Nilai biomassa ikan pelagis besar menunjukkan pola peningkatan seiring dengan bertambahnya kedalaman, sebaliknya biomassa ikan- ikan pelagis kecil terlihat menurun seiring bertambahnya kedalaman. Hal ini, sesuai dengan swimming layer ikan-ikan pelagis kecil yang berada pada strata kedalaman yang relatif lebih dangkal dibandingkan ikan pelagis besar. 


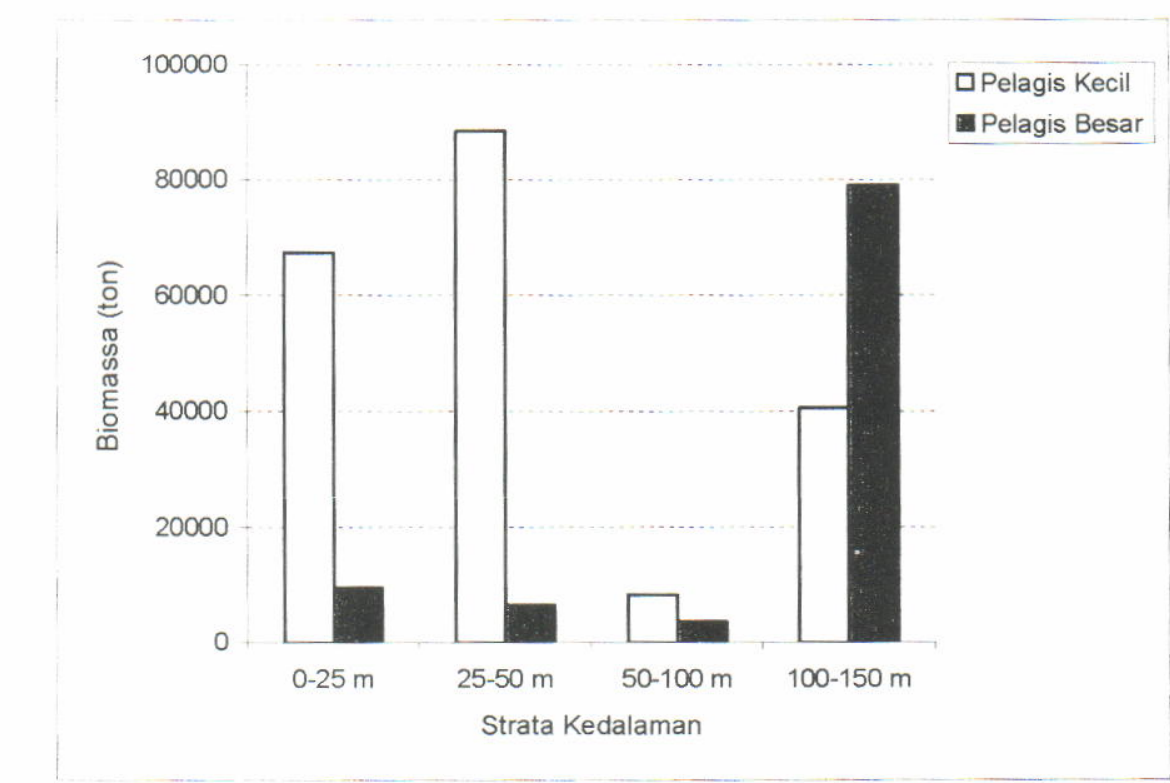

Gambar 6 .

Nilai biomassa ikan pelagis kecil dan ikan pelagis besar per kedalaman.

Figure 6 .

Biomass of the small pelagic and large pelagic fish by depth stratum.

\section{KESIMPULAN}

1. Nilai dugaan biomassa perairan Teluk Tomini sampai dengan kedalaman $150 \mathrm{~m}$ adalah 303.624 ton. Biomassa ini merupakan nilai biomassa yang mewakili lahan 17.220 mil $^{2}$, atau lebih dari $59.000 \mathrm{~km}^{2}$ sehingga didapatkan kepadatan total ikan di perairan Teluk Tomini 5. 140 ton $\mathrm{km}^{-2}$

2. Biomassa total untuk ikan pelagis kecil adalah 204.695 ton atau $67 \%$ dari total biomassa, sedangkan untuk ikan pelagis besar adalah 98.930 atau $33 \%$ dari total biomassa.

3. Biomassa ikan pelagis cenderung menurun seiring bertambahnya kedalaman, sedangkan biomassa ikan pelagis besar memiliki kecenderungan meningkat seiring bertambahnya kedalaman.

\section{DAFTAR PUSTAKA}

Armstrong, F. 1986. Target strength of sandee/s. Int. Count. Explor. Sea CM 1986/B:5, 6 hal.

Arnaya, I. N. 1991b. Diktat kuliah akustik kelautan II. Proyek Peningkatan Perguruan Tinggi. Institut Pertanian Bogor. Bogor.

Edwards, J. I. \& Armstrong F. 1984. Target strength experiments on caged fish. Scott. Fish. Bull.,48, $12-20$.
Gulland. J. A. 1983. Fish stock assesment, a manual of basic methods. FAONiley Series on Food and Agriculture, Vol.I. Wiley. Chichester. 223 hal.

Hutahean, A. A. 1999. Studi tentang target strength ikan pelagis besar di perairan Selat Sunda. Skripsi (tidak dipublikasikan). Program Studi IImu Kelautan. Fakultas Perikanan dan IImu Kelautan. Insitut Pertanian Bogor. Bogor.

Kailola, P. J. \& Tarp T. G. 1984. Trawled fishes of Southern Indonesia and Northwestern Australia. Australian Development Assistance Bereau. Directorat General of fisheries. Indonesia. German Agency for Technical Cooperation.

Laevastu, T. \& M. L. Hayes. 1981. Fisheries oceanography and ecology. Fishing News Book Ltd.

MacLennan, D. N. 1990. Acoustical measurement of fish abundance. J Acoust. Soc. Am. (62): 1-15

MacLennan, D. N. \& E. J. Simmonds. 1992. Fisheries acoustics. Chapman \& Hall. London. 325 hal.

SIMRAD. 1993b. SIMRAD EP 500 (Operational manual). Horten-Norway.

SIMRAD EY 500. 1997. Portable scientific echosounder. Horten-Norway. 